\title{
Various Histological Types of Renal Cell Carcinoma Associated With Hereditary Papillary Renal Cell Carcinoma (HPRCC): a Case Report
}

\author{
Sophie FERLICOT ( $\square$ sophie.ferlicot@aphp.fr) \\ Pierre-Alexandre Just \\ APHP: Assistance Publique - Hopitaux de Paris \\ Eva Compérat \\ APHP: Assistance Publique - Hopitaux de Paris \\ Etienne Rouleau \\ Gustave Roussy Institute: Gustave Roussy \\ Frédérique Tissier \\ APHP: Assistance Publique - Hopitaux de Paris \\ Christophe Vaessen \\ APHP: Assistance Publique - Hopitaux de Paris \\ Stéphane Richard \\ EPHE: Ecole Pratique des Hautes Etudes
}

Université Paris-Saclay Faculté de Médecine: Universite Paris-Saclay Faculte de Medecine https://orcid.org/0000-0003-4124-9227

\section{Case Report}

Keywords: renal cell carcinoma, hereditary papillary renal cell carcinoma, MET

Posted Date: July 26th, 2021

DOI: https://doi.org/10.21203/rs.3.rs-736943/v1

License: 두 (i) This work is licensed under a Creative Commons Attribution 4.0 International License. Read Full License 


\section{Abstract}

Background: Hereditary papillary renal cell carcinoma (HPRCC) is a rare autosomal dominant disease characterized by the development of multiple and bilateral papillary type I renal cell carcinomas (RCC) and papillary adenomas caused by activating mutations in the MET proto-oncogene. Classically, distinctive histological features of RCC are described according to the familial renal cell carcinoma syndrome. To date, no clear cell RCC has been reported in HPRCC syndrome.

Case presentation: We describe the case of a 51-year-old man with a germline MET mutation, who developed numerous papillary tumors but also unexpectedly clear cell renal cell carcinomas. During the follow-up, an adrenal metastasis was observed seven years after the initial diagnosis corresponding to a clear cell RCC metastasis. Using FISH, the metastatic tumor presented a trisomy of chromosomes 7 and 17. These genomic alterations are usually detected in papillary RCC, highlighting the potential link between both histological subtypes of tumors and the HPRCC syndrome.

Conclusions: The pathologist must be aware that the presence of a non-papillary RCC associated with numerous papillary tumors should not exclude the diagnostic suspicion of HPRCC and thus to perform a thorough genomic study.

\section{Background}

It is now estimated that $3 \%$ of renal cell carcinomas (RCC) are linked to an inherited predisposition [1]. To date, a dozen of genes involved in autosomal dominant syndromes have been identified, the main ones being: VHL, MET, FLCN, FH, TSC1, TSC2, and SDHB [2]. The most frequent inherited RCC syndrome is von Hippel-Lindau disease with a birth incidence of $1 / 36,000$ caused by germline mutations in the VHL tumor suppressor gene predisposing to the occurrence of clear cell RCC. Hereditary papillary RCC (HPRCC) is an extremely rare disorder with an estimated incidence of $1 / 500,000[3,4]$. It is characterized by the development of multiple and bilateral papillary type I RCC and papillary adenomas caused by activating mutations in the MET proto-oncogene [3]. Familial RCC syndromes are often characterized by bilateral and multifocal tumors in the kidney, generally of the same histological type. Presence of various tumor histological types is a rare event, classically described for Birt-Hogg-Dubé (BHD) syndrome with chromophobe, oncocytic or both components. In this report, we describe for the first time the association between papillary tumors and clear cell RCC in a patient with HPRCC syndrome.

\section{Case Presentation Clinical history}

The patient, a 51-year-old man, without a familial background of RCC, underwent computed tomography for hypertension investigation in 2008 that revealed bilateral and multifocal renal tumors. Initially, eight left partial renal tumorectomies were performed. After this initial surgery, an active surveillance was established for the right kidney. In 2010, the magnetic resonance imaging revealed that right nodules had grown and a second surgery was performed on the right kidney with five renal tumorectomies. During the follow-up, the patient underwent a left adrenalectomy in 2015 for RCC metastasis. Since this date, the stability of the kidney nodules allowed an annual radiological assessment and follow-up without specific therapy.

\section{Pathological findings}

The diameters of tumor nodules ranged from $0.1 \mathrm{~cm}$ to $4 \mathrm{~cm}$. Pathological features are summarized in Table 1. Three nodules measuring respectively 2.5, 3 and $4 \mathrm{~cm}$ had typical histological features of clear cell RCC with ISUP grade 1 (Fig. 1a). The other nodules showed typical histological features of papillary tumors, either type 1 papillary RCC (5 tumors) or papillary adenomas often numerous (Fig. $1 \mathrm{~b}$ and c). One of the papillary lesions (specimen $\mathrm{n}^{\circ} 8$ ) was reclassified from renal cell carcinoma to adenoma after reassessment in light of the updated 2016 WHO criteria allowing papillary adenomas to be up to $1.5 \mathrm{~cm}$, with no pseudocapsule [1]. Four nodules with a diameter less than $1.5 \mathrm{~cm}$ remained interpreted as papillary renal cell carcinomas due to encapsulation. The left adrenal nodule corresponded to a clear cell RCC metastasis (Fig. 1d). 
Table 1

Summary of pathological, immunohistochemistry, and FISH features of the 13 renal tumorectomies and the left adrenalectomy

\begin{tabular}{|c|c|c|c|c|c|c|c|c|c|c|c|}
\hline $\begin{array}{l}\text { Specimen } \\
\text { number }\end{array}$ & Laterality & Location & $\begin{array}{l}\text { Size* } \\
(\mathrm{cm})\end{array}$ & $\begin{array}{l}\text { Histological } \\
\text { type of } \\
\text { largest } \\
\text { tumor }\end{array}$ & $\begin{array}{l}\text { Type of } \\
\text { other } \\
\text { tumors }\end{array}$ & P504S & CK7 & CAIX & CD10 & $\begin{array}{l}\text { VHL } \\
\text { deletion }\end{array}$ & $\begin{array}{l}\text { Trisomy } \\
7 / 17\end{array}$ \\
\hline 1 & $\mathrm{R}$ & $\begin{array}{l}\text { upper } \\
\text { pole }\end{array}$ & 4 & $\begin{array}{l}\text { clear cell } \\
\text { RCC }\end{array}$ & & + & + & + & + & no & no \\
\hline 2 & $\mathrm{R}$ & $\begin{array}{l}\text { external- } \\
\text { upper } \\
\text { pole }\end{array}$ & 3 & $\begin{array}{l}\text { clear cell } \\
\text { RCC }\end{array}$ & & NA & NA & NA & NA & NA & NA \\
\hline 3 & $\mathrm{R}$ & $\begin{array}{l}\text { posterior } \\
\text { face }\end{array}$ & 0.3 & $\begin{array}{l}\text { papillary } \\
\text { adenoma }\end{array}$ & & NA & NA & NA & NA & NA & NA \\
\hline 4 & $\mathrm{R}$ & $\begin{array}{l}\text { posterior } \\
\text { upper } \\
\text { pole }\end{array}$ & 0.8 & $\begin{array}{l}\text { papillary } \\
\text { RCC }\end{array}$ & & + & + & - & - & no & yes \\
\hline 5 & $\mathrm{R}$ & $\begin{array}{l}\text { anterior } \\
\text { upper } \\
\text { pole }\end{array}$ & 0.3 & $\begin{array}{l}\text { papillary } \\
\text { adenoma }\end{array}$ & & + & + & - & - & no & no \\
\hline 6 & $\mathrm{R}$ & $\begin{array}{l}\text { lower } \\
\text { pole }\end{array}$ & 1 & $\begin{array}{l}\text { papillary } \\
\text { RCC }\end{array}$ & & + & + & - & - & NA & NA \\
\hline 7 & $\mathrm{R}$ & $\begin{array}{l}\text { lower } \\
\text { pole }\end{array}$ & 0.1 & $\begin{array}{l}\text { papillary } \\
\text { adenoma }\end{array}$ & & + & + & - & - & no & no \\
\hline 8 & $\mathrm{R}$ & $\begin{array}{l}\text { upper } \\
\text { pole }\end{array}$ & 1 & $\begin{array}{l}\text { papillary } \\
\text { adenoma }\end{array}$ & & NA & NA & NA & NA & NA & NA \\
\hline 9 & $\mathrm{~L}$ & $\begin{array}{l}\text { anterior } \\
\text { face }\end{array}$ & 2.5 & $\begin{array}{l}\text { clear cell } \\
\text { RCC }\end{array}$ & & + & focal & + & + & yes & no \\
\hline 10 & $\mathrm{~L}$ & $\begin{array}{l}\text { anterior } \\
\text { face }\end{array}$ & 0.6 & $\begin{array}{l}\text { papillary } \\
\text { RCC }\end{array}$ & & NA & NA & NA & NA & no & yes \\
\hline 11 & $\mathrm{~L}$ & $\begin{array}{l}\text { anterior } \\
\text { face }\end{array}$ & 0.1 & $\begin{array}{l}\text { papillary } \\
\text { adenoma }\end{array}$ & $\begin{array}{l}\text { papillary } \\
\text { adenomas }\end{array}$ & + & + & - & $+/-$ & no & no \\
\hline 12 & $\mathrm{~L}$ & $\begin{array}{l}\text { upper } \\
\text { pole }\end{array}$ & 1.5 & $\begin{array}{l}\text { papillary } \\
\text { RCC }\end{array}$ & $\begin{array}{l}\text { papillary } \\
\text { adenomas }\end{array}$ & NA & NA & NA & NA & NA & NA \\
\hline 13 & $L$ & $\begin{array}{l}\text { upper } \\
\text { pole }\end{array}$ & 1 & $\begin{array}{l}\text { papillary } \\
\text { RCC }\end{array}$ & $\begin{array}{l}\text { papillary } \\
\text { adenomas }\end{array}$ & + & + & - & - & no & 7 only \\
\hline 14 & $L$ & $\begin{array}{l}\text { Adrenal } \\
\text { gland }\end{array}$ & 3.1 & $\begin{array}{l}\text { Clear cell } \\
\text { RCC } \\
\text { metastasis }\end{array}$ & & + & focal & + & + & no & yes \\
\hline
\end{tabular}

Considering the presence of different histological types, diagnosis of BHD syndrome was initially suspected and a molecular analysis of FLCN gene was first performed. Absence of germline FLCN mutation led to realize another genetic tests in 2010 targeting $V H L$ and MET genes. Finally, a germline MET mutation c.3712G > A, p.(Val1238lle) was found.

An immunohistochemical analysis using TMA and fluorescent in situ hybridization (FISH) analysis were performed on ten representative nodules selected on hematoxylin and eosin-stained sections from the original blocks (2 clear cell carcinomas, 5 papillary carcinomas, 2 papillary adenomas and 1 metastasis) and are summarized in Table 1. Fluorescence in situ hybridization (FISH) was performed for $V H L$ loss and gain (trisomy) of chromosome 7 or 17 in the same specimens than immunohistochemical analysis.

Deletion of chromosome $3 p$ was assessed using a probe cocktail containing probes to chromosome 3p25.3 and centromere 3 (Z-2084, Zytovision). Chromosomes 7 and 17 gains were assessed using a probe cocktail containing probes to centromere 7 and centromere 17 (Z-2081, Zytovision). For each slide, 50 tumor cell nuclei were scored for probe signals under the fluorescence microscope with $\times 60$ 
magnification. $V H L$ loss was defined using a cut-off value of $30 \%$ of tumor cells with less $3 p 25.3$ signals than centromere 3 signals. Gain of chromosomes 7 and 17 was defined using a cut-off value of $20 \%$ of tumor cells with $\geq 3$ centromere 7 and/or 17 signals.

By immunohistochemistry, all papillary lesions were positive for vimentin, cytokeratin 7 (Fig. 2a), and all had stronger labeling for alphamethylacyl-coA-racemase (p504S). Papillary lesions were uniformly negative for CAIX. CAIX (Fig. 2b) and CD10 labeled only the 3 clear cell RCC. Using FISH, VHL deletion was observed in only one case corresponding to the clear cell RCC resected in 2010. Trisomy of chromosomes 7 or 17 was encountered in 3 cases of papillary RCC and in the adrenal ccRCC metastasis (Fig. 2c).

\section{Discussion And Conclusions}

We report for the first time the occurrence of synchronous bilateral kidney tumors of different histological subtypes (clear cell RCC and papillary RCC) in a patient whom the genetic analysis showed the presence of a germline mutation in the MET oncogene, $\mathrm{p}$. (Val1238Ile).

HPRCC is a very rare inherited syndrome characterized by the development of numerous papillary adenomas or papillary type 1 carcinomas [2, 5]. Germline mutations within the MET gene were first identified by a genome-wide analysis of HPRCC families then somatic MET mutations were also found in some sporadic papillary type 1 RCC $[3,6,7]$. The MET proto-oncogene is located on chromosome 7q31 and encodes the receptor for hepatocyte growth factor (HGF). HGF binding to MET results in autophosphorylation of tyrosines in the met kinase domain leading to activation of MAPKinase and PI3K-AKT signal cascades that drive effectors involved in cell proliferation, migration, and invasion [8, 9]. In cases of germline $M E T$ mutations, there is a ligand-independent constitutive kinase activation $[3,10]$. Cytogenetic studies showed that the papillary renal carcinomas harboring MET mutations also had trisomy of chromosome 7, resulting from duplication of the chromosome harboring the mutated MET allele [11].

Classically, a specific histological type is described according to each inherited syndrome; for example, clear cell RCC in VHL disease and papillary tumors in HPRCC syndrome. However, recently, two cases of biphasic squamoid RCC (BSARCC) mixed with type 1 papillary RCC have been reported in a familial context of hereditary papillary RCC associated with MET mutation.

Immunohistochemical features with expression in both populations of CK7, AMACR and vimentin were consistent with a link between BSARCC and type I papillary RCC [12]. Several hypotheses could be considered to explain the occurrence of various histological types: (1) common metabolic pathway but other cases of mixed histological subtypes should then have been reported; (2) specific histological type according to the type of mutation as described previously for clinical manifestations in VHL disease [13]. Against this possibility, to date, it has not been described any genotype-phenotype correlations in HPRCC. Furthermore, the patient presented one the most frequent MET known mutations. No report has described clear cell RCC or coexistence of other histologic subtypes in the same kidney of a patient with HPRCC except the report of a biphasic squamoid RCC; and (3) both clear cell RCC and papillary RCC are originated from proximal tubules and we can not exclude that additional genetic events of key regulatory genes may push a tumor towards a particular phenotype.

FISH analysis showed trisomy 7 and/or 17 in 3 out of 4 tested cases of papillary RCC and more unexpectedly in the clear cell RCC metastasis. This data would be in favor of a molecular link between both histological subtypes. Trisomy 7 and/or 17 were not observed in the papillary adenomas, perhaps influenced by difficulty evaluating sufficient numbers of tumor cells in microscopic papillary adenomas and a potential lower rate of these alterations in adenomas compared to papillary carcinomas. Interestingly, among the 3 clear cell RCC, $V H L$ deletion was observed in only one case.

In summary, it is important to remember that some genomic alterations might be associated with synchronous bilateral kidney tumors with different histological types. The pathologist must be aware that the presence of a non-papillary RCC associated with numerous papillary adenomas or type I carcinomas should not exclude the diagnostic suspicion of HPRCC and thus to perform a thorough genomic study.

\section{Abbreviations}

BHD: Birt-Hogg-Dubé; FISH: Fluorescence in situ hybridization ; RCC: renal cell carcinoma; HPRCC: Hereditary papillary renal cell carcinoma

\section{Declarations}


Ethics approval and consent to participate: Written informed consent was obtained from the patient for genetic analysis.

Consent for publication: Not applicable.

Availability of data and materials: All the data regarding the findings are available within the manuscript.

Competing interests: The authors declare that they have no competing interests.

Funding: This work was supported in part by grants from the French "Ligue Nationale contre le Cancer" (Comités des Yvelines et du Val de Marne).

Authors' contributions: Conception and design: Sophie Ferlicot and Stéphane Richard; collection and assembly of data: Pierre-Alexandre Just, Eva Compérat, Etienne Rouleau, Frédérique Tissier and Christophe Vaessen; final approval of the manuscript: all authors.

Acknowledgements: Not applicable.

\section{References}

1. Moch H, Humphrey PA, Ulbright TM, Reuter VE. WHO Classification of Tumours of the Urinary System and Male Genital Organs. $4^{\text {th }}$ ed. Lyon: WHO Press; 2016.

2. Schmidt LS, Linehan WM. Genetic predisposition to kidney cancer. Semin Oncol. 2016;43:566-74.

3. Schmidt L, Duh FM, Chen F, et al. Germline and somatic mutations in the tyrosine kinase domain of the MET proto-oncogene in papillary renal carcinomas. Nat Genet. 1997;16:68-73.

4. Maher ER. Hereditary renal cell carcinoma syndromes: diagnosis, surveillance and management. World J Urol. 2018;36:1891-8.

5. Schmidt LS, Nickerson ML, Angeloni D, et al. Early onset hereditary papillary renal carcinoma: germline missense mutations in the tyrosine kinase domain of the met proto-oncogene. J Urol. 2004;172:1256-61.

6. Haas NB, Nathanson KL. Hereditary kidney cancer syndromes. Adv Chronic Kidney Dis. 2014;21:81-90.

7. Cancer Genome Atlas Research Network, Linehan WM, Spellman PT, et al. Comprehensive molecular characterization of papillary renal-cell carcinoma. N Engl J Med. 2016;374:135-45.

8. Dharmawardana PG, Giubellino A, Bottaro DP. Hereditary papillary renal carcinoma type I. Curr Mol Med. 2004;4:855-68.

9. Tovar EA, Graveel CR. MET in human cancer: germline and somatic mutations. Ann Transl Med. 2017;5:205.

10. Schiering N, Knapp S, Marconi M, et al. Crystal structure of the tyrosine kinase domain of the hepatocyte growth factor receptor cMet and its complex with the microbial alkaloid K-252a. Proc Natl Acad Sci USA. 2003;100:12654-9.

11. Zhuang Z, Park WS, Pack S, et al. Trisomy 7-harbouring non-random duplication of the mutant MET allele in hereditary papillary renal carcinomas. Nat Genet. 1998;20:66-9.

12. Chartier S, Méjean A, Richard S, Thiounn N, Vasiliu V, Verkarre V. Biphasic Squamoid Alveolar Renal Cell Carcinoma: 2 Cases in a Family Supporting a Continuous Spectrum With Papillary Type I Renal Cell Carcinoma. Am J Surg Pathol. 2017;41:1011-2.

13. Richard S, Gardie B, Couvé S, Gad S. Von Hippel-Lindau: how a rare disease illuminates cancer biology. Seminars in Cancer Biology. 2013;23:26-37.

\section{Figures}



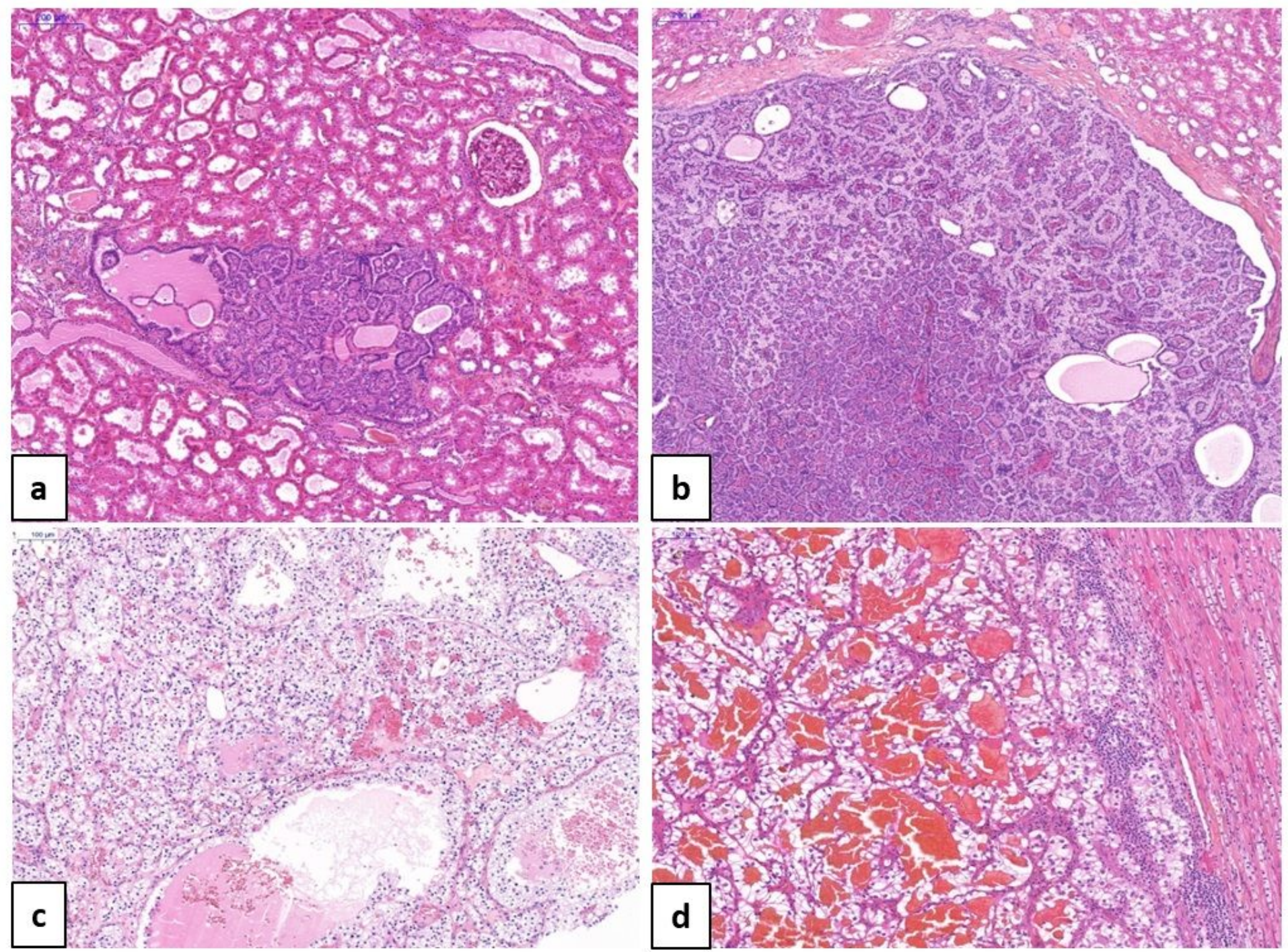

\section{Figure 1}

(a) Papillary adenoma is characterized by an encapsulated papillary proliferation arising in the renal cortex. (b) Papillary RCC, type 1 is characterized by papillary cores covered by a single layer of tumour cells and circumscribed by a fibrous capsule. (c) Clear cell RCC with alveolar nests of tumour cells and microscopic cysts. (d) Clear cell RCC with blood-filled microscopic cysts metastatic to adrenal gland. 


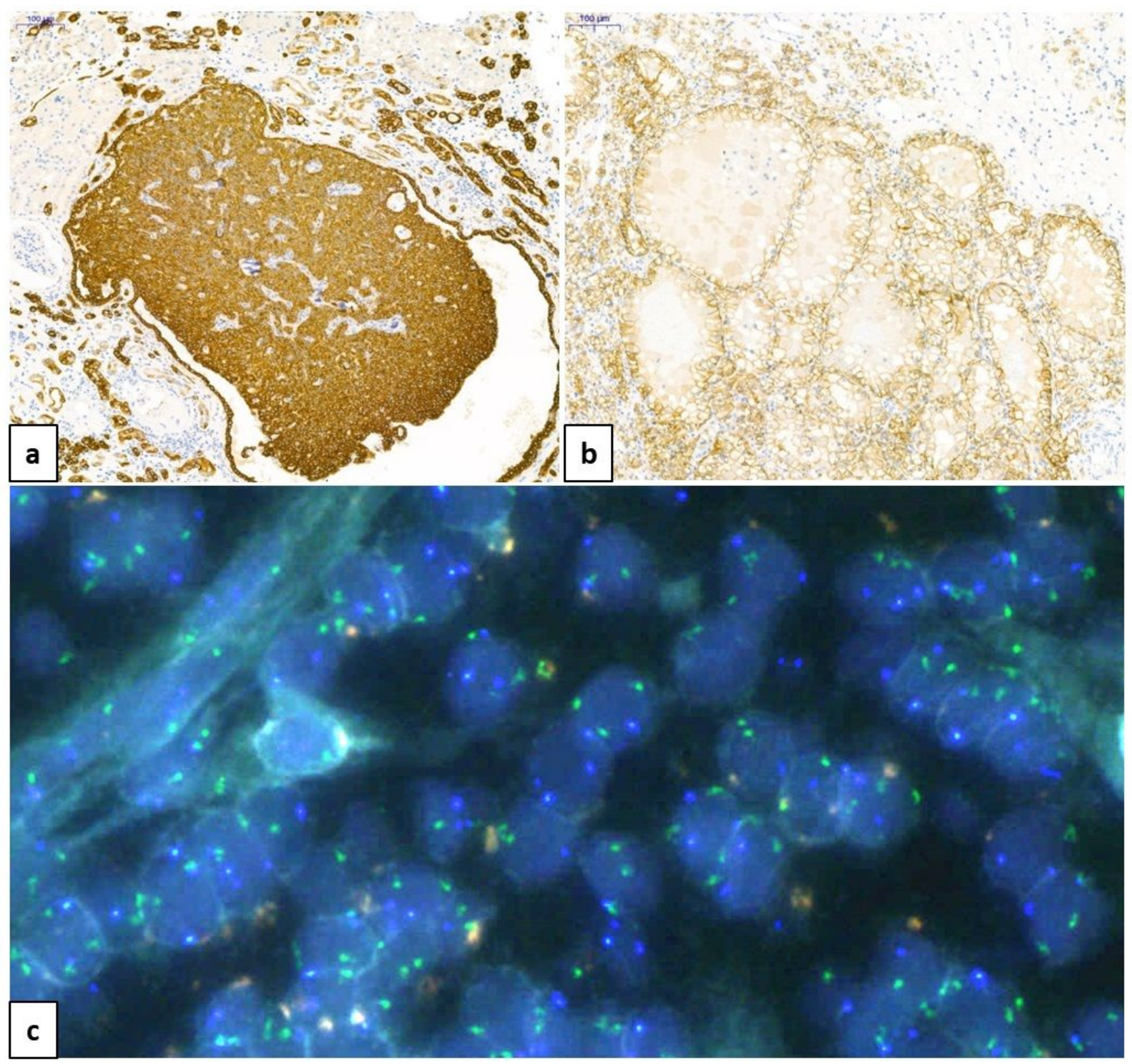

\section{Figure 2}

Immunohistochemical staining revealed the papillary adenoma to be cytokeratin 7 positive (a), whereas the clear cell RCC exhibited stronger membranous labeling for CAIX (b). Centromere 7 (green signals) and centromere 17 (blue signals) FISH evidenced a 7/17 trisomy in a papillary carcinoma (c).

\section{Supplementary Files}

This is a list of supplementary files associated with this preprint. Click to download.

- CAREChecklist.pdf 